\title{
Assessment of the Implementation of the Universal Basic Education Programme in South West, Nigeria: Issues, Problems and Prospects
}

\author{
${ }^{1}$ Eunice A. Oladimeji, ${ }^{2}$ Tunji Henry Ogunyebi \\ ${ }^{1}$ State Universal Basic Education Board \\ ${ }^{2}$ Department of Integrated Science, College of Education \\ Nigeria
}

\begin{abstract}
This study assessed the extent to which the UBE programme has been implemented in South West, Nigeria. Three research questions and three hypotheses guided the study. The research design for this study is a descriptive research of the survey and ex-post facto designs. The population for the study consisted of students, teachers of both primary and the Junior secondary schools and SUBEB personnel in the South Western States, Nigeria. A sample of 1370participants was drawn from the population of 3,254,454 of Headteachers, Principals, Teachers, Education personnel and students. The sample for the study comprised of 100 Headteachers, 50 Principals, 420 Teachers, 200 Education personnel/ managers and 600 students. Three instruments were developed and used to obtain the data for this study. They are: Teachers assessment of implementation of UBE questionnaire (TAIUBEPQ), Questionnaire for Managers of UBE programme (QMUBEP) and Students questionnaire on perception of level of success of UBE programme (SQPLSUBE). The statistics used in the analysis included mean ratings and percentage. The hypotheses were tested using Chi square statistical method. A mean cut-off point of 2.50 was used for decision making. Any mean score of 2.50 and above was accepted as being significantly different while any mean score below 2.50 was rejected as not being significantly different. All hypotheses were tested at 0.05 level of significance. The findings revealed that the proportion of qualified teachers engaged in Southwest zone was not in accordance and lower than what is provided for in the UBE implementation guideline and the level of teachers' motivation, retraining and retention have been partial and not in conformity with its implementation guidelines among others. The study recommended provision of more quantity and quality teachers and government should make provision and prepare for training of qualified teachers. In addition, companies and well to do individuals should be encouraged to contribute to the development of UBE. Regular seminars/conferences should be organized for teachers, personnel and other stakeholders to update their knowledge and enlighten them on usefulness of facilities provided and their adequate implementation in each of the schools in the geo-political zone.
\end{abstract}

\section{Introduction}

Societies through ages have one form of education or the other, whether indigenous or western. Education varies from place to place and from time to time. Education, defined as permanent change in behavior as a result of learning consists of all efforts (conscious or incidental) made by a society to accomplish set objectives, which are considered to be desirable in terms of the individual, as well as the societal needs [13].

Ifeanyi [11] added that prior to the introduction of Western Education in Nigeria by the Christian missionaries; there were other systems of education viz: Traditional and Islamic systems of education in Nigeria. Traditionally, various communities had ways of educating their young ones according to their values and norms. The system of education was aimed at enabling the young ones to acquire the life patterns of their society. Education has therefore, been a social process in capacity building and maintenance of society since the creation of human beings. All over the world, primary education has been regarded as the most important as well as the most patronized by people. This perhaps may be due to the fact that it is the foundation of the whole educational pursuit, which is expected to provide literacy and enlightenment to the citizens. Nigeria has therefore; adopted education as an instrument par excellence for national development (FGN, 2004) and this is reflected in the National Policy on Education.

The reduction of illiteracy to the barest minimum by 2015 by world nations and the achievement of item two of the Millennium Development Goals (MDGs) prompt the introduction of the Universal Basic Education (UBE) programme in Nigeria. The Millennium Development Goals (MDGs) item two adopted by world nations in 2000 proposed that, by 2015 , children of educable age should have free, affordable and accessible education. The item is a response to the world conference of Education For ALL (EFA)" held in Jomitten, Thailand from 5th to 9th March 1990, which was the major trigger for the birth of basic education. Obanya [14] observed that towards the end of the twentieth century, the Nigerian education could not play the role of a prime mover of political and socio- economic development. This was as a result of the fact that education 
suffered the same faith as the Nation itself and these increases in schools did not give rise to any merging qualitative improvement. He added that schools suffered lack of infrastructure, decay of facilities, demoralized teachers, low teacher quality, high teacher pupil ratio among others leading to poor pupil performances in examinations, poor access, poor retention, wide geographical/gender /social disparities in educational opportunities. The effectiveness of basic education to eradicate or reduce level of illiteracy as well as enhance development has been an issue of concern to all the stakeholders of basic education. This has been one of the reasons for the introduction of Universal Basic Education in place of the former Universal Primary Education in Nigeria.

It is a programme which Ocheta and Olele [15] say is a mandatory education policy for Nigerian children irrespective of such bottlenecks and handicaps associated with location, occupation, religion, race and gender. The quality of teaching and learning in schools to ensure the acquisition of relevant skills for lifelong learning at the basic education level appears to be a thing of worry to individuals. Subsequently, there have been series of complaints from the public and concerned citizens on the learning that takes place in the school where most learners and teachers cannot read and write in English effectively. Furthermore, there is likely to be weak organizational system in terms of possession of appropriate capacity to effectively translate the objectives of the programs into realizable implementation strategies. No wonder then that, some structures are cited in schools where they are not needed. For instance, in a school with less than 150 pupils in one of the South western states, three blocks of 3 classrooms each was cited in the school. This shows the weak capacity of our Education Managers to actually merge demand and supply of facilities with enrolment and needs of the school. These complaints coupled with series of actions taken by the stakeholders, development partners and concerned bodies present a questionable and doubtful situation. It is from this situation that, the researcher developed interest in embarking on this study. However, the major interest in this study is whether these objectives are being achieved or not. It becomes necessary to assess the implementation of UBE programme objectives in order to ascertain its role as a positive instrument of change and development.

\section{Review of Related Literature}

The review of related literature is carried out under the following sub-headings:

\subsection{The Universal Basic Education (UBE) as a reform Programme}

The Universal Basic Education Programme (UBE) was introduced by the Federal government of Nigeria in 1999. It was to remove distortions and inconsistencies in basic education delivery and reinforce the implementation of the National Policy on education as well as to provide greater access to, and ensure quality of basic education throughout Nigeria. Universal Basic Education is the transmission of fundamental knowledge to all facets of the Nigerian society from generation to generation. It has three main components - universal, basic and education. Universal connotes a programme that is meant for all facets of the society - the rich and poor, the physically fit and physically challenged, the brilliant and dull, the regular students and the dropouts including every other individual that is ready to acquire knowledge. 'The term basic connotes that which is fundamental or essential indicating that basic education is the starting point in the acquisition of knowledge and that it is for all citizens.

It is that type of education that can help an individual function effectively in the society [2]. The law establishing UBEC stipulates a 9-year formal schooling, adult literacy and non-formal education, skill acquisition programs and the education of special groups such as nomads and migrants, girl child and women, Al-majiri, street children and disabled group [1]. The Universal Basic Education Commission (UBEC) was also established and charged with the following functions as stated in UBEC [3];

1. Prescribe minimum standards for basic education throughout the country

2. Co-ordinate, supervise and monitor the implementation of the UBE programme

3. Initiate and monitor the execution of specific programs for the attainment of UBE objectives after consultation with all state governments and stakeholders

4. Sensitize and mobilize stake holders for their effective involvement and participation in the UBE programme

5. Collate, analyze and publish information relating to basic education in Nigeria

6. Carry out regular personnel audit in each state of the federation

7. Disburse UBE funds to states, local governments and any other Federal government agency that is implementing any aspect of the UBE programme based on approved guidelines and others. 


\subsection{Infrastructural Facilities for the Implementation of UBE Programme}

Halak [10] identifies educational facilities as the main factors contributing to academic performances in a school system. Without these facilities, effective instruction and learning may not take place. Such facilities include: school uniforms, exercise books, pencils/pens, textbooks, buildings, furniture and an environment that is conducive to learning. Denga [8], observes that the introduction of UBE in 1976 brought about a plethora of changes including an over-whelming increase in enrolment, teachers training, teachers' motivation among others. Proper teaching cannot be done in unorthodox makeshift classrooms because pupils' learning in quantity and quality will be intangible and poor due to lack of facilities. The lack of adequate infrastructure in the Nigerian education programme is thus another issue without any contention. The evidence of dilapidated school buildings is everywhere and sometimes in places one does not even expect; even in reputed government schools. To further stress the importance of teaching facilities, Alka[6] laments thus: How can our children enjoy potentialities inherent in these instructional facilities which include developing in the child scientific attitudes such as honesty, patience and appreciative feelings, helping a child in a real life situation rather than memorization and regurgitation of facts and finally adding to the child's knowledge base such as creativity, carefulness, openmindedness, accuracy and objectivity? Infrastructural facilities are important components of the schools and their absence or insufficient supply to schools could hinder teachers' performance [12].

From the foregoing, it can be observed that there is urgent need for an environment in Nigerian schools that is conducive for teaching and learning and for good facilities to be provided for the UBE programme for it to effectively achieve its aims and objectives. The provision of furniture and equipment is very important for the implementation of the UBE programme. Many scholars opined that the provision of facilities, especially in the rural schools, is far below expectation $[5,16]$.

Education, needless to say, is a priority sector in every well-meaning society. Thus, Butch [7] as cited in Jayeoba (2007) referred to it as a major force in economic, intellectual, social and cultural empowerment. Its value in bringing about character and attitudinal change ranks as important as its ability to reshape human potentials for desired development. With the introduction of Universal Basic Education, it is believed that development of Nigeria will be accelerated because of inherent value in education. Attesting to this, Preece [18] submitted that education is a proven contributor to reducing poverty. This culminated the Nigeria emphasis in provision of basic education for all and which has to be compulsory. It was recommended that if UBE will contribute meaningfully to our educational development, teachers have to be creative, innovative and inspiring, teaching materials should be adequate and well utilized facilities such as school buildings, desks, tables, chairs, water, electricity, library and access roads need to be made available [3].

\section{Statement of the Problem}

Despite all the various efforts of government in the improvement of Education, there seems to be continuing appearance of school age children hawking on the streets, failure rate of pupils in schools is unprecedented while the school system appears to have been plagued with various vices such as moral decadence, truancy, indiscipline and total neglect coupled with the rate of illiteracy which tends to be high. Therefore, many attempts that have been made to ensure universal access, right to free and qualitative education in this direction seem to have produced no appreciable positive result.

The UBE programme has the potential to achieve the above, make the citizens productive and useful to themselves, the country and the world at large if well implemented. Unfortunately, after 10 years of existence of UBE programme, young children are still roaming about on the streets begging and hawking during school hours [4], the population of under-aged mothers (young mothers who should be in secondary schools) still looms high, and school drop-out cases appear to remain intractable (about $9.3 \%$ in primary schools) transition from primary to secondary school remains at about $61 \%$ and about $16 \%$ to post UBE (Road Map to Nigerian Education sector, 2009). The development of consciousness to Education and its vigorous promotion in the country also appears to be a mirage. The teachers of UBE also appear to be dissatisfied with their remuneration and conditions of service in addition to poor or inadequate provision of teaching and learning facilities like libraries, laboratory equipment, books among others. The morale of teachers also appears to remain low indicating poor motivation, while the curriculum of UBE also appears not to be implemented fully in UBE Schools. It is against this background that this research is out to assess the implementation of UBE programme in South-West Geo-political zone.

\section{Purpose of the Study}

The purpose of the study is to assess the implementation of various aspects of the UBE programs in the South Western States particularly in relation to the achievement of its stated goals and objectives. This implies assessing and determining the adequacy, relevancy, efficiency, effectiveness, 
appropriateness or otherwise of the aspects of inputs, process and products of UBE. In other words, it aimed at identifying any areas and sources of either strengths or weakness in the UBE programs with respect to the achievement of the objectives of the programme.

Again, the study investigated the existing goals and objectives of the UBE programme in terms of availability of resources, both human, material and implementation strategies. It also investigated whether these resources can raise the standards of the students learning achievements, outcomes and school quality. The study also identified the specific strategies put in place to implement the UBE programme and determined the extent to which the strategies are successfully implemented to contribute to the achievement of the UBE objectives in South Western states.

\section{Research questions}

The following research questions have been generated to guide and direct the investigation:

1. What is the quality of UBE teachers in terms of professional training in the various states in SouthWest Geo-political zone of Nigeria?

2. To what extent has the implementation of UBE programme been successful in the South-West Geopolitical zone of Nigeria?

3. What is the level of teacher motivation, retraining and retention in primary and junior secondary in UBE schools in South-West Geopolitical zone of Nigeria?

\section{Hypotheses}

The following hypotheses were formulated and tested at 0.05 level of significance thus:

1. The proportion of qualified teachers in terms of training in this zone is not significantly different from the one hundred percent $(100 \%)$ provided for in the UBE implementation guideline.

2. The extent of UBE implementation success in this zone is not significantly different from the one hundred percent $(100 \%)$ provided for in the UBE implementation guideline.

3. The level of teachers' motivation, retraining and retention in primary and junior secondary schools in this zone is not significantly different from the one hundred percent $(100 \%)$ provided for in the UBE implementation guideline.

\section{Significance of the Study}

This study will provide empirical evidence to the various stakeholders particularly, governments, programme managers, administrators, policy makers among others on the extent to which the programme has helped to improve the quality of schooling and the education sector in general. It will also provide information on the understanding of the relationships that exist between education inputs and achievements levels as well as the identification of what factors make or mar the development or success and the extent to which the programme objectives are achieved. It is hoped that this will be used as a basis for promoting effective provision of infrastructure and learning materials in UBE schools in South-West Geo-political zone of Nigeria for effective teaching and learning. The study will also be useful to SUBEB as it will provide them with information that will assist them in controlling dropout rate in UBE programme. The study will also enlighten the parents/society on the prevailing realities in UBE programme and help them see the existing disparity in rural and urban areas in regard to UBE programme which will pose a challenge to those lagging behind and propel them to improve in order to catch up. This will help in achieving education for all in the zone particularly and the nation at large; thus, the nation can reap the gains of a literate society.

Another significance of this study is that it will assess the implementation process of UBE so far, identify loopholes and help ascertain the extent to which the quality free and compulsory basic education has reached the minorities of South-West Geo Political zone of Nigeria. Finally, the study will uncover impediments to effective implementation of UBE programme and suggest solutions which when adopted and implemented can guarantee more success for the programme in South-West Geo political zone of Nigeria particularly and the nation at large.

\section{Methodology}

The study adopted a descriptive research of the survey and ex-post fact designs. The population of the study consist of 3,254,454 of Head teachers, Principals, Teachers, Education personnel and students. Purposive sampling and proportionate stratified random sampling techniques was used in this study. A sample of 1,370 participants was drawn from the population of $3,254,454$ of Headteachers, Principals, Teachers, Education personnel and students. The sample for the study comprised of 100 Headteachers, 50 Principals, 420 Teachers, 200 Education personnel/ managers and 600 students. Three instruments were developed and used to obtain the data for this study. They are; Teachers assessment of implementation of UBE questionnaire (TAIUBEPQ), Questionnaire for Managers of UBE programme (QMUBEP) and Students questionnaire on perception of level of success of UBE programme (SQPLSUBE). 
The questionnaire was validated by experts in Tests and Measurement from the Faculty of Education, Ekiti State University, Ado Ekiti, Nigeria. The questionnaire was trial tested using 60 teachers, 30 personnel and 80 students respectively, who were not part of the sampled population. The data collected were analyzed using Cronbach Alpha statistics to establish its reliability which yielded 0.78 . The coefficient indicated high internal consistency.

The hypotheses were tested using Chi-square statistical method. A mean cut-off point of 2.50 was used for decision making. Any mean score of 2.50 and above was accepted as being significantly different while any mean score below 2.50 was rejected as not being significantly different. The inferential statistic of chi-square(x2) test of goodness of-fit was used to test the hypotheses at 0.05 level of significance.

\section{Results/Outcome}

From Table 1, the chi-square calculated value of 5.67 is greater than chi-square critical value of 3.841 thus, the null hypothesis is rejected. Hence, the proportion of qualified teachers in terms of training in South-West zone is significantly different from the one hundred percent $(100 \%)$ provided for in the UBE was accepted as being significantly different implementation guideline. The mean sores of 4.23 which is greater than 2.50 cut-off was also accepted as being significant.

From Table 2, the chi-square calculated value of 6.28 is greater than chi-square critical value of 3.841 thus, the null hypothesis is rejected. Hence, the extent of UBE implementation success in the SouthWest zone is significantly different from the one hundred percent $(100 \%)$ provided for in the UBE implementation guideline. The mean sores of 4.17 which is greater than 2.50 cut-off was also accepted as being significant.

From Table 3, the chi-square calculated value of 5.44 is greater than chi-square critical value of 3.841 thus, the null hypothesis is rejected. Hence, the level of teachers' motivation, retraining and retention in primary and junior secondary schools in the SouthWest zone is significantly different from the one hundred percent $(100 \%)$ provided for in the UBE implementation guideline. The mean sores of 3.98 which is greater than 2.50 cut-off was also accepted as being significant.

\section{Discussion of Findings}

The outcome of the hypothesis 1 which state that the proportion of qualified teachers in terms of training in the South-West zone is not significantly different from the one hundred percent $(100 \%)$ provided for in the UBE implementation guideline is not in accordance with the submission of Obanya
[14], who observed that towards the end of the twentieth century, the Nigerian education could not play the role of a prime mover of political and socioeconomic development. This was as a result of the fact that education suffered the same faith as the Nation itself and these increases in schools did not give rise to any merging qualitative improvement. He added that schools suffered lack of infrastructure, decay of facilities, demoralized teachers, low teacher quality, high teacher pupil ratio among others leading to poor pupil performances in examinations, poor access, poor retention, wide geographical/ gender /social disparities in educational opportunities. This means that the quantity and quality of teachers in the South-West have not yet met the standard requirement of SUBEB. The outcome of the hypothesis 2 which state that the extent of UBE implementation success in the SouthWest zone is not significantly different from the one hundred percent $(100 \%)$ provided for in the UBE implementation guideline is in line with the submission Oluwole and Akpakwu [5,12,16], that opined that the provision of facilities, especially in the rural schools, is far below expectation. For this reason, one can understand that to achieve the goal of the UBE programme, enough textbooks and other instructional materials are needed. From the foregoing, it can be observed that there is urgent need for an environment in Nigerian schools that is conducive for teaching and learning and for good facilities to be provided for the UBE programme for it to effectively achieve its aims and objectives. The provision of furniture and equipment is very important for the implementation of the UBE programme.

The outcome of the hypothesis 3 which state that the level of teachers' motivation, retraining and retention in primary and junior secondary schools in the South-West zone is not significantly different from the one hundred percent $(100 \%)$ provided for in the UBE implementation guideline is not in line with the submission of Denga[8], who observes that the introduction of UBE in 1976 brought about a plethora of changes including an over-whelming increase in enrolment, teachers training, teachers motivation among others. Proper teaching cannot be done in unorthodox makeshift classrooms because pupils' learning in quantity and quality will be intangible and poor due to lack of facilities and adequate incentives. In this case, when teachers are encouraged with adequate facilities and packages, it yields maximum learning outcomes.

\section{Conclusion}

1. The proportion of qualified teachers engaged in South-west zone was not in 
Table 1. The proportion of qualified teachers in terms of training in South-West zone

\begin{tabular}{ll}
\hline Calculated $\left(\mathrm{X}^{2}\right)$ & $=5.6 \quad$ Degree of Freedom: $=5$ Level of Significance: $=0.05$ \\
\hline Table value of $\left(\mathrm{X}^{2}\right)$ & $=3.84$ at 0.05 Mean scores $=4.23$
\end{tabular}

Decision: $\mathrm{P}<0.05$ (that is 3.84 is less than 5.67 ).

Table 2. The extent of UBE implementation success in the South-West zone

\begin{tabular}{|c|c|c|c|}
\hline Calculated X2 & $=6.28$ Degree of Freedom: & $=5 \mathrm{Level}$ of Significance: & $=0.05$ \\
\hline Table value of (X2) & $=3.84$ at $0.05 \mathrm{Mean}$ scores & $=4.17$ & \\
\hline
\end{tabular}

Table 3. the level of teachers' motivation, retraining and retention in primary and junior secondary schools in the South-West zone

\begin{tabular}{ll}
\hline Calculated X2 & $=5.44$ Degree of Freedom: $=5$ Level of Significance: $=0.05$ \\
\hline Table value of $(\mathrm{X} 2)$ & $=3.84$ at 0.05 Mean scores $=3.98$
\end{tabular}

Decision: $\mathrm{P}<0.05$ (that is 3.84 is less than 5.44).

accordance and lower than what is provided for in the UBE implementation guideline.

2. The UBE implementation programme was fairly successful, not perfectly in accordance and lower than what is provided for in the UBE implementation guideline.

3. The level of teachers' motivation, retraining and retention in primary and junior secondary schools in South-West zone of Nigeria has not been consistent with the UBE act (2004), rather, it has been partial and not in conformity with its implementation guidelines. The teaching of the major Nigerian languages is not done neither are craftsmen and women employed to teach their crafts to pupils in the zone. For UBE to achieve the desired results, the implementations would need to go back to the drawing board and ensure strict compliance to the provision of the UBE Act [19] and the implementation guidelines.

\section{Recommendations}

Based on the findings of this research, the following recommendations have been put forward;

1.The study has made recommendations towards to provision of more quantity and quality teachers, government should make provision and prepare for training of qualified teachers. In these regards, there should be massive employment of qualified teachers to fill in the vacancies in the teaching service in the South-West geo-political zone of Nigeria. The unqualified teachers should be sent on in-service training. Also, regular seminars/ conferences should be organized during holidays to update the knowledge of serving teachers in the geo-political zone.

2. The government, companies and well to do individuals as well as philanthropic individuals / organizations should be encouraged to contribute to the development of UBE through the provision of teaching materials/infrastructure in UBE schools. On the other hand, this can be made mandatory so that all companies and contractors operating in the geopolitical zone must pay some percentages of their profits to the development of UBE to ensure usefulness of facilities provided and adequate implementation in each of the schools of the programme in the geo-political zone and reduce illiteracy and its associated effects in the geopolitical zone particularly and the country in general.

3. There should be adequate provision and maintenance of facilities in urban and rural areas in form of physical structures likes school building, school grounds, classrooms, laboratory, literary, school hall, staff rooms among others. These should be of high quality and quantity to commensurate with the number of Pupils environment in every school. 
4. Regular seminars/ conferences should be organized for teachers, personnel and other stakeholders to update their knowledge and enlighten them on usefulness of facilities provided and their adequate implementation in each of the schools in the geo-political zone.

\section{References}

[1] Aderinoye, R. (2007). Mergers of Education parastatals.A revisit, This Day, January 2nd, 2007.

[2] Adewole, E. (2010). Assessment of provision of Services under UBE Scheme in Southern Nigeria. Retrieved on 26th June, 2009 from http://www.bnet.com/

[3] Adu, A. (2008). Effective Management of Primary Education in Nigeria.The Challenges before the Universal Basic Education Commission (UBEC). Multidisciplinary Journal of Research and Development, 7(1), 103-108.

[4] Ajaegbo, N.A (2009). Implementation of Universal Basic Education: Matters Arising. In Ada, $\mathrm{N}$; Maduewesi, B. U and Ihebereme, C. I (Ed) (2009). Emergent issues in Universal basic Education Programme in Nigeria.Onitsha: west \& Solomon Publishing Coy Ltd.

[5] Akpakwu, S.O. (2008). Essentials of education management.Makurdi: Jalim Press Nigeria Ltd.

[6] Alka, G.O. (2009). Supervision as an instrument of teaching and learning effectiveness: Challenges for the Nigerian practice. Nigerian Journal of Curriculum Studies, 2, 46-51.

[7] Butch G (2006): Evaluating educational programme and products (ed). Eaglewood Cliff, N.J. Educational Technology.

[8] Denga, D.I (1996). Human Engineering for high Productivity in industrial and other work organizations.Calabar: Rapid Educational Publishers Limited.

[9] Federal Republic of Nigeria Gazette (2004). No. 66, Vol. 91, Act No. 8. PPA113-A124.

[10] Hallak, J. (1990). Investing in to the future: Setting educational priorities in the developing world.Oxford Pergamum Press.

[11] Ifeanyi, W. (2004): Dimension of monitoring and evaluation of the UBE programme in Nigeria. Education today.
[12] Ker, B.O \&Oluwole M.U. (2006). Personal management in Tertiary institutions of learning.In P. $\mathrm{T}$. Ortese (ed) Towards functional and qualitative education in Nigeria. Makurdi:Destiny Ventures pp 377-386.

[13] Labo-popoola et al (2009): Universal Basic Education in Nigeria: challenges and way forward. Medwell journals vol4 issue 6

[14] Obayan, P. (2008) (2) Education and the Nigerian Society Revised the UBE as a People's Oriented Programme being the 2000 Prof. J. A. Majasan first Anniversary Memorial Lecture Ibadan.

[15] Ocheta, W \&Olele, C.N (2009). Emergent Issues in Universal Basic Education in Nigeria, Onitsha: West and Solomon Publishing coy Ltd.

[16] Oluwole, M.U. (2007). School management and supervision.Makurdi: Destiny Ventures.

[17] Omojuwa, J. (1999, April). Performance of final year NCE students in the national common entrance examination.In U. Onwuka (Ed.), Curriculum development for Africa (pp.75- 93). Onitsha: Africana Fep.

[18] Preece, M. (2006): Alternative approaches to outcomes assessment for post-secondary vocational educational. Centre Focus.

[19] Universal Basic Education Commission, (2009). 2006 National assessment of Universal Basic Education Programme (NAUBEP) Abuja: Universal Basic Education Commission. 